\title{
Evaluation of methane emissions from Taiwanese paddies
}

\author{
Chen-Wuing Liu*, Chung-Yi Wu \\ Department of Bioenvironmental Systems Engineering, National Taiwan University, Taipei, Taiwan 10617 PO China
}

Received 4 November 2003; received in revised form 31 March 2004

\begin{abstract}
The main greenhouse gases are carbon dioxide, methane and nitrous oxide. Methane is the most important because the warming effect of methane is 21 times greater than that of carbon dioxide. Methane emitted from rice paddy fields is a major source of atmospheric methane. In this work, a methane emission model (MEM), which integrates climate change, plant growth and degradation of soil organic matter, was applied to estimate the emission of methane from rice paddy fields in Taiwan. The estimated results indicate that much methane is emitted during the effective tillering and booting stages in the first crop season and during the transplanting stage in the second crop season in a year. Sensitivity analysis reveals that the temperature is the most important parameter that governs the methane emission rate. The order of the strengths of the effects of the other parameters is soil $\mathrm{pH}$, soil water depth (SWD) and soil organic matter content. The masses of methane emitted from rice paddy fields of Taiwan in the first and second crop seasons are 28,507 and 350,231 tons, respectively. The amount of methane emitted during the second crop season is 12.5 times higher than that emitted in the first crop season. With a $12 \%$ reduction in planted area during the second crop season, methane emission could be reduced by $21 \%$. In addition, removal of rice straw left from the first crop season and increasing the depth of flooding to $25 \mathrm{~cm}$ are also strategies that could help reduce annual emission by up to $18 \%$.

(C) 2004 Elsevier B.V. All rights reserved.
\end{abstract}

Keywords: Methane; Rice paddy field; Emission; Sensitivity analysis

\section{Introduction}

Over the last century, the greenhouse effect has increased the mean global temperature by $0.3-0.6$ ${ }^{\circ} \mathrm{C}$, and will increase it by a further $1.5-4.5{ }^{\circ} \mathrm{C}$ by 2050 (Houghton et al., 1990; IPCC, 1992). Methane, carbon dioxide, nitrous oxide and chlorofluorocarbons are the most important greenhouse gases, and

* Corresponding author. Tel.: +886-2-2362-6480; fax: +886-22363-9557.

E-mail address: 1cw@gwater.agec.ntu.edu.tw (C.-W. Liu). have strong infrared absorption bands, which trap some of the thermal radiation reflected by the earth's surface. Before the industrial revolution, the atmospheric concentration of methane was $0.7 \mathrm{ppmv}$. By 2000, the methane concentration had increased to 1.75 ppmv (Wuebbles and Hayhoe, 2002), and was continuing to increase at an annual rate of $1 \%$ (Schimel, 2000).

Rice paddies constitute a major source of methane $\mathrm{CH}_{4}$, and may be responsible for $20 \%$ of the global total methane emission (Houghton et al., 1990; IPCC, 1992). The production of rice must increase from the current level of 460-758 million tons by the year 2020 
to meet demand (IRRI, 1988). Associated methane emissions may increase by $40-50 \%$ (Bouwman, 1991; Anastasic et al., 1992). Therefore, the assessment of $\mathrm{CH}_{4}$ emission from rice paddies is important in predicting atmospheric $\mathrm{CH}_{4}$ concentration (Segers, 1998).

$\mathrm{CH}_{4}$ is emitted from rice paddies to the atmosphere along via three pathways diffusion, ebullition and plant-mediated transport (Fig. 1) (Schutz et al., 1989; Delwiche and Cicerone, 1993). The emission of methane by diffusion from subsurface soil to flood water, before entering the atmosphere represents only $1 \%$ of such emissions from paddies. Ten percent of the methane emitted from paddies accumulates as gas bubbles and is emitted by ebullition; this pathway is the main one for transferring gas into the atmosphere during the transplanting stage. The emission of methane from rice plants to the atmosphere explained the remaining $90 \%$ of methane emission from paddies (Holzapfel-Pschorn et al., 1986). Thus, rice plants are the main conduit of methane gas emitted from rice paddies into the atmosphere.

Emission is strongly related to plant growth, the decomposition of soil organic matter and atmospheric conditions. The parameters that affect the emissions of methane from paddy fields include temperature, soil $\mathrm{pH}$, soil organic matter content, the oxidation-reduction (redox) potential and the depth of floodwater. The optimal temperature for the activity of the majority of methanogens is between 30 and $40{ }^{\circ} \mathrm{C}$ (Neue and Scharpenseel, 1984). In the $15-30{ }^{\circ} \mathrm{C}$ temperature range, raising the temperature by $10{ }^{\circ} \mathrm{C}$ increases the methane production rate by a factor of 2.5-3.5 (Schutz et al., 1989). The $Q_{10}$ value has been used to describe the temperature dependence of the production and oxidation of methane. $Q_{10}$ values determined in the incubation experiments with temperature as single varying factor for methane production, resulting in a large range variation (Segers, 1998). Large variation in

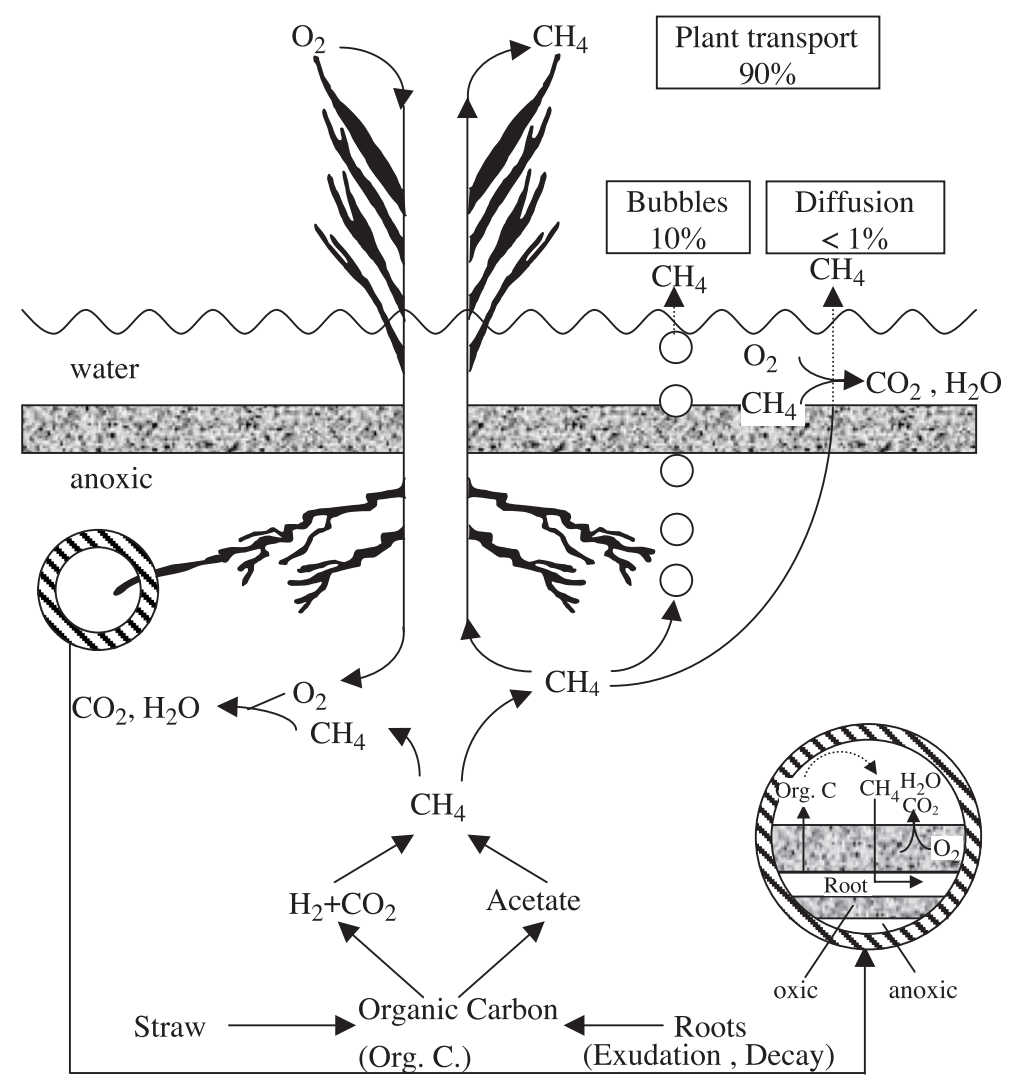

Fig. 1. Three methane emission pathways in a paddy field (Schutz et al., 1989). 
reported $Q_{10}$ value of methane production could be due to the anomalous temperature behavior of the methanogenic themselves and due to the interaction of underlying processes. An increasing temperature increases rates of electron acceptor reduction, which results in lower election acceptor concentrations which has an additional positive effect on methane production. Some studies have found extraordinarily strong temperature responses for $\mathrm{CH}_{4}$ production with $Q_{10}$ values greater than 20 (Segers, 1998). This too is likely to reflect responses at multiple stages in the food web, as low temperature inhibits $\mathrm{H}_{2}$ production, shuts down carbon dioxide reduction, and forces shifts in the specific methanogenic pathways involved. Thus, the overall temperature effect may result from multiplicative responses of each group of organisms rather than just the effect on any one (Schimel, 2002).

The type and content of the soil organic matter directly affects the production of methane. A slightly alkaline environment (generally) favors the formation of $\mathrm{CH}_{4}$. The optimal $\mathrm{pH}$ for several species of methanogens is between 6.4 and 7.1. A soil pH of below 6 inhibits the growth of methanogens (Wang et al., 1993). A sufficiently low redox potential (Eh) is required to enable the formation of $\mathrm{CH}_{4}$, since methanogenic bacteria can metabolize only in strictly anaerobic environments. The Eh must be below $-200 \mathrm{mV}$ to cause significant $\mathrm{CH}_{4}$ production (Yamane and Sato, 1964; Kludze et al., 1993). The flooding leads to a low redox potential, establishes an anaerobic soil environment for the mathanogens, and increases the rate of $\mathrm{CH}_{4}$ production (Sebacher et al., 1986).

The $\mathrm{CH}_{4}$ release rate determined from point measurements have been extrapolated to the regional level, and the empirical methane emission rate has been correlated with a few factors (such as temperature and the method of irrigation) to estimate the rate of emission of methane from paddy fields in Taiwan (Liu et al., 1996; Yang and Chang, 1998, 2001). Recently, Yang et al. (2003) used the measured rate of emission of methane from paddy fields and the emission factors recommended by the IPCC $(1997 \mathrm{a}, \mathrm{b})$ to estimate the amount of methane emitted from paddy fields in Taiwan between 1990 and 2000. The emitted amount of methane, estimated from the rates measured in the falls within the range provided in the IPCC guidelines with multiple aer- ation treatment. The IPCC classifies the methane emission flux based only on the method of irrigation and the first and second crop periods. The other important factors - the soil $\mathrm{pH}$, the soil organic mater content, the redox potential and the depth of the floodwater - are not considered. Quantitative results concerning the emission of methane from rice paddies in Taiwan thus remain lacking.

In the last decade, knowledge of methane production and methane consumption has increased considerably. This increase in knowledge has been exploited to develop different process models (Cao et al., 1995a; Walter et al., 1996; Watson et al., 1997). Cao et al. (1995a) developed a methane emission model (MEM), that considered supplies of carbon substrate involved in forming methanogens by the primary production of rice and the degradation of soil organic matter, direct environmental controls of methanogenesis, and the balance between $\mathrm{CH}_{4}$ production and consumption by methanotrophic oxidation. The model was validated as being able satisfactorily to calculate the $\mathrm{CH}_{4}$ emission rate and seasonal variations. The model, when coupled with supporting data sets, complements the spatial and dynamic analyses of $\mathrm{CH}_{4}$ emission from rice paddies within a framework of climate-plant soil interactions. Additionally, the MEM was applied to estimate the emissions of methane from the entire area in China in which rice is grown (Cao et al., 1995b).

In this work, the MEM (Cao et al., 1995a) was used to evaluate the emission of methane from rice paddies in Taiwan. The amounts of methane emitted in the first and second crop seasons were evaluated and compared. Based on these estimates, a strategy for reducing methane emission was proposed to lower effectively the amount of methane emitted from rice paddies in Taiwan, and thus decease the contribution of such to global warming and climate change.

\section{Materials and methods}

The MEM was applied to estimate $\mathrm{CH}_{4}$ emissions from Taiwan's rice paddies. The input data of MEM, including the soil organic matter, the rate of photosynthesis, the area of rice leaves, the number of hours of sun daily, the temperature and the $\mathrm{pH}$ of the soil 
were collected from 15 irrigation associations and other agencies to evaluate the amount of methane emitted by rice paddies in 2001 .

Data concerning the soil organic matter in the northern, central and southern, and eastern parts of Taiwan were collected from the field by Huang (1996), Wang and Hsieh (1997) and Chang (1996), respectively. One percent organic matter content in the soil is equivalent to the application of 12 tons of rice straw per unit ha of a paddy. The organic content of stubble is added to the amount of organic matter in the first crop season to yield the total amount considered in the second crop season. The ratio of the total dry weight of the stem and the stubble to that of only the stubble is approximately 1:0.11 (Barder and Martine, 1976); stubble consists of $45 \%$ organic matter (Lin, 1995). The soil textures were provided by the irrigation associations.

The average rate of photosynthesis of rice is $40-50$ $\mathrm{CO}_{2} \mathrm{mg} \mathrm{dm}^{-2} \mathrm{~h}^{-1}$ (Chang, 1988). The leaf area per plant was calculated from the data measured by Oritani and Yoshida (1984) in the rice blooming stage and extrapolated to other stages. The data on the daily number of hours of sunshine were taken from the web site of the Central Weather Bureau (http://www.cwb. gov.tw/index-f.htm). The number of rice plants per unit hectare was calculated with reference to a survey by Chang (1996). The proportions of the rhizodeposition of carbon in the five growth stages were set to $50 \%, 40 \%, 30 \%, 20 \%$ and $10 \%$, respectively.

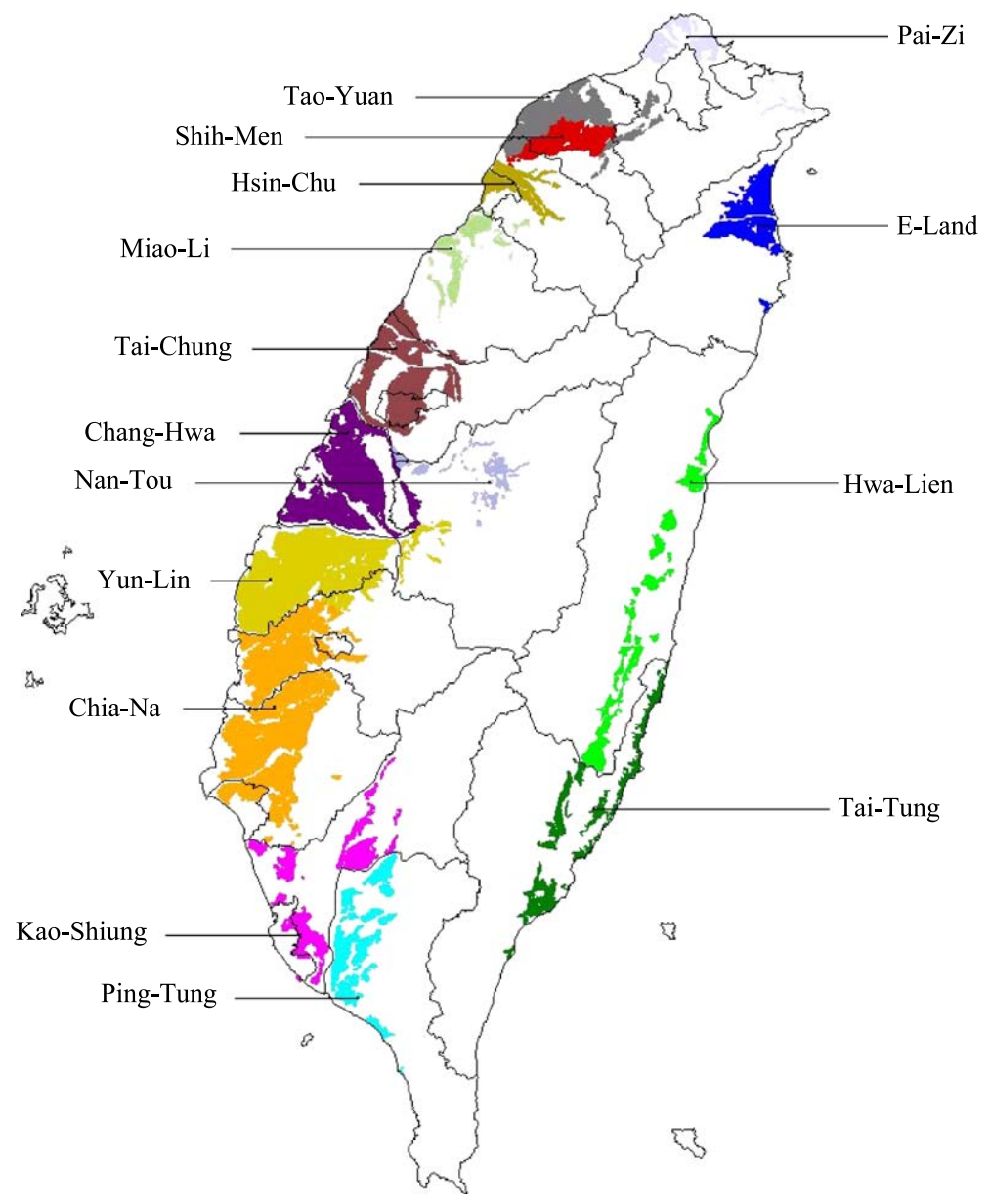

Fig. 2. Geographic distribution of paddy areas of 15 irrigation associations in Taiwan. 
The monthly mean temperature in each rice growth stage was also taken from the web site of the Central Weather Bureau. Paddies in Taiwan are irrigated using the rotational irrigation method. Rotational irrigation is highly efficient. The depth of the floodwater is maintained at range $3-5 \mathrm{~cm}$ during the transplanting and effective tillering stages, to prevent the rice stems from being broken. The depth of the flood water increases to $5-10 \mathrm{~cm}$ in the booting and blooming stages and gradually falls to $2-3 \mathrm{~cm}$ to keep the soil wet in the mature stage. The rice is then harvested using an agromachine. In this work, the depth of the floodwater was set to $4 \mathrm{~cm}$ in the transplanting and effective tillering stages, to $5 \mathrm{~cm}$ in the booting stage, to $7.5 \mathrm{~cm}$ in the blooming stage, and to $2.5 \mathrm{~cm}$ in the mature stage. The soil $\mathrm{pH}$ was taken from data measured in the field (Huang, 1996; Wang and Hsieh, 1997; Chang, 1996).

Paddies in Taiwan are usually fertilized using ammonia fertilizer, which does not substantially inhibit the emission of methane. Therefore, the effect of mineral fertilization on the $\mathrm{CH}_{4}$ emission rate is negligible. Additionally, $\mathrm{CH}_{4}$ oxidation rates in each of the five rice growth stages of $50 \%, 60 \%, 70 \%, 80 \%$ and $90 \%$ are assumed, respectively.

The study area was approximately 300,000 ha, covering all paddy fields in Taiwan (Fig. 2). Fifteen irrigation associations manage this 300,000 ha of paddies. The 15 irrigation associations are divided geographically; those in the northern part are Pai-Zi, Tao-Yuan, Shih-Men, Hsin-Chu and Miao-Li; those in the central part are Tai-Chung, Nan-Tou, Chang-Hua and Yu-Lin; those in the southern part are Chia-Nan, Kao-Shiung and Ping-Tung, and those in the eastern part are E-Land, Hua-Lien and Tai-Tung. Taiwan has two rice-growing seasons annually. The first crop season is from February to July, and lasts for 120140 days. The temperature gradually increases as the season changes from spring to summer. The second crop season is from August to the following January, and lasts 110-150 days. This crop season includes the end of the summer, and continues through autumn to winter; the temperature decreases from high to low.

The rice growth period of a total of 110 days is divided into five stages, including transplanting, effective tillering, booting, blooming and maturity. The durations of each the stages are 15, 35, 25, 15 and 20 days, in that order.

\section{Results and discussion}

\subsection{Model validation}

Chang (1996) measured the rate of emission of methane in the first and second crop periods at the agricultural experimentation station of National Taiwan University. The measured data are herein compared to the results estimated using MEM. The soil $\mathrm{pH}$ was 5.6; the content of soil organic matter was $28 \%$, and the proportions of sand, clay and silt were $45.3 \%, 20.1 \%$ and $34.6 \%$, respectively. The temperatures during the five rice growth stages in the first and second crop seasons were 21, 25, 28.5, 29.5 and $30{ }^{\circ} \mathrm{C}$, and $32,29.5,25.5,21.5$ and $17{ }^{\circ} \mathrm{C}$, respectively. The emission of methane from the paddy in each rice growth stages was measured five times using a homemade acrylic chamber (of length $40 \mathrm{~cm}$, width $40 \mathrm{~cm}$ and height $65 \mathrm{~cm}$, with a volume of approximately 96 1) (Chang, 1996). The rate of emission of methane was determined at $0.5 \mathrm{~h}$ intervals for $1.0 \mathrm{~h}$ by measuring the changes in methane concentration (the net change between the emission and sinking of methane) in the acrylic chamber. The concentration of emitted methane was analyzed by gas chromatography, using FID. The rate of emission of methane rate $\left(\mathrm{mg} \mathrm{m}^{-2} \mathrm{~h}^{-1}\right)$ during each growth stage was computed using the following fsuation (Rolston, 1986).

$f=\left(\frac{V}{A}\right)\left(\frac{\Delta c}{\Delta t}\right)$

where $f$ is the rate of emission of methane $\left(\mathrm{mg} \mathrm{m}^{-2}\right.$ $\left.\mathrm{h}^{-1}\right) ; V$ is the volume of the chamber above the soil $\left(\mathrm{m}^{3}\right) ; A$ is the cross-sectional area of the chamber $\left(\mathrm{m}^{2}\right) ; \Delta c$ is the difference between the concentration at time zero and that at time $\mathrm{t}\left(\mathrm{mg} \mathrm{m}^{-3}\right)$, and $\Delta t$ is the interval between two samplings $(\mathrm{h})$.

Fig. 3 plots the measured and simulated rates of the emission of methane during the five growth stages in the first and second crop seasons (Table 1). Each plotted data point represents a mean value and \pm standard deviation of five measurements. The corresponding rates during the first and second crop seasons closely correlated, with $R^{2}$ values of 0.82 and 0.83 , respectively. A $\chi^{2}$ test was performed to determine whether the measured and simulated methane 


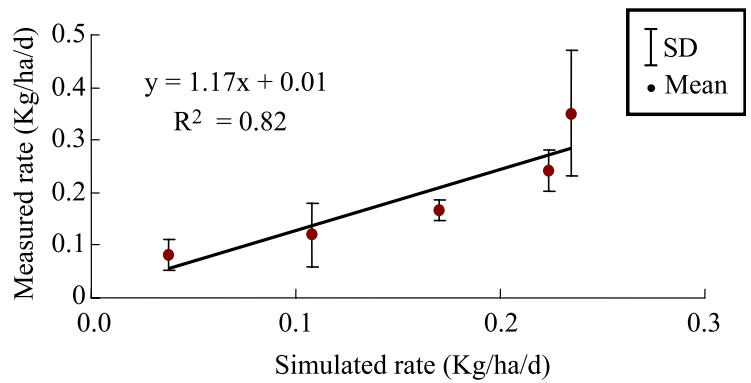

(a) First crop season

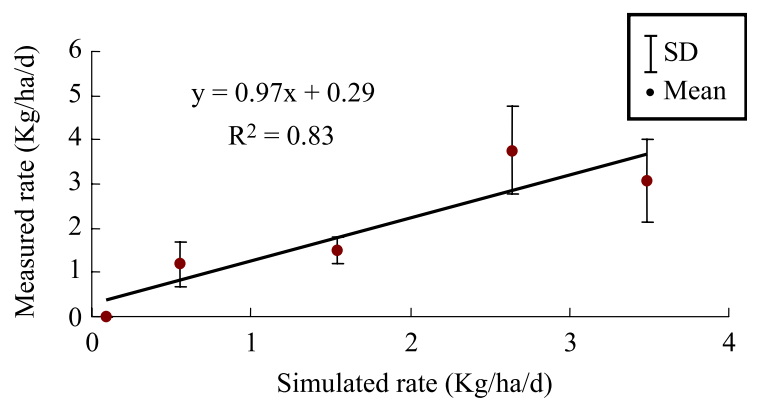

(b) Second crop season

Fig. 3. Comparison of the rates of emission of methane estimated using MEM and measured in the field, for the first and second crop seasons. S.D. is the standard deviation.

emission rates in the first and second crop seasons differed significantly.

The hypotheses in the $\chi^{2}$ lest is as follows.

$\mathbf{H}_{\mathbf{0}}$. The measured and simulated methane emission rates are not significantly different.

$\mathbf{H}_{\mathbf{a}}$. The measured and simulated methane emission rates are significantly different.

The computed $\chi_{0}^{2}$ values for the rates of emission of methane during the first and second crop seasons were 0.11 and 1.35 , respectively, both smaller than $\chi_{0.05,4}^{2}=9.49 . \chi_{0}^{2}=0.11$ (or 1.35$)<\chi_{0.05,4}^{2}=9.49$, so hypothesis Ho that the measured and simulated methane emission rate do not differ significantly was accepted. The $\chi^{2}$ hypothesis test indicates that the MEM can be used to estimate the rate of emission of methane from rice paddies in Taiwan.

\subsection{Simulated results}

\subsubsection{First crop season}

Fig. 4(a)-(d) plots simulated methane emission rates during the five rice growth stages in the first crop season in the paddies in the northern, central, southern and eastern regions. The rates of emission of methane generally increased with the temperature and reached a maximum during the blooming stage. The effect of the oxidation of methane is stronger than that of temperature; thus, the rate of emission of methane fell significantly during the mature stage. Although the soil organic content in the southern region was lower than that in the northern region, the soil $\mathrm{pH}$ and temperature in the former exceeded those in the latter, resulting in average highest and lowest emission rates of 1.33 and $0.16 \mathrm{~kg} \mathrm{ha}^{-1}$ day $^{-1}$ among the four regions. The highest rate was in the southern region and the lowest in the northern region.

In the northern region, Tao-Yuan exhibited a higher rate of emission of methane, $0.23 \mathrm{~kg} \mathrm{ha}^{-1}$ day $^{-1}$ than the other four irrigation associations, because its soil is neutral. Of the four irrigation associations in the central region, Nan-Tou, emitted methane at the lowest rate of $0.06 \mathrm{~kg} \mathrm{ha}^{-1} \mathrm{day}^{-1}$, because soil there is acidic and the ambient temperature is low. The rates of emission of methane did not vary much across the southern region, because all areas have similar environmental conditions. The acidic soil in the E-Land irrigation association was associated with the lowest

Table 1

Simulated and measured rates of emission of methane $\left(\mathrm{kg} \mathrm{ha}^{-1}\right.$ day $\left.^{-1}\right)$ during rice growth stages in the first and second crop seasons

\begin{tabular}{lllll}
\hline Growth stage & $\begin{array}{l}\text { First crop } \\
\text { simulated }\end{array}$ & $\begin{array}{l}\text { First crop } \\
\text { measured }\end{array}$ & $\begin{array}{l}\text { Second crop } \\
\text { simulated }\end{array}$ & $\begin{array}{l}\text { Second crop } \\
\text { measured }\end{array}$ \\
\hline Transplanting & 0.108 & 0.12 & 4.881 & 3.077 \\
Effective tillering & 0.170 & 0.166 & 3.685 & 3.763 \\
Booting & 0.223 & 0.242 & 2.149 & 1.502 \\
Bloom & 0.234 & 0.35 & 0.775 & 1.19 \\
Mature & 0.038 & 0.082 & 0.122 & 0.005 \\
\hline
\end{tabular}



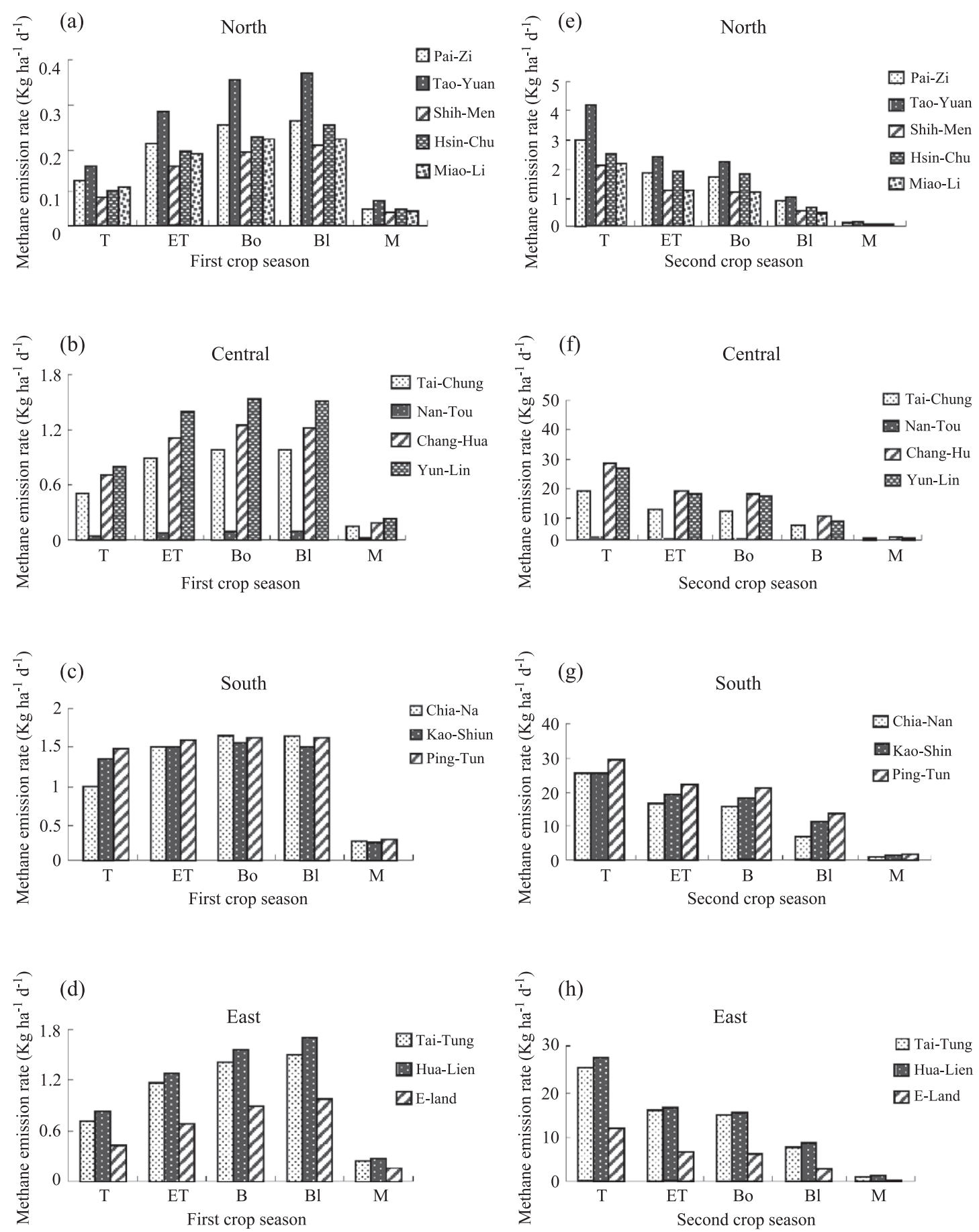

Fig. 4. Rates of emission of methane during five rice growth stages in the first and second crop seasons in the northern, central, southern and eastern regions of Taiwan. Transplanting (T), Effective Tillering (ET), Booting (Bo), Blooming (Bl) and Mature (M). 
rate of emission of methane, $0.62 \mathrm{~kg} \mathrm{ha}^{-1} \mathrm{day}^{-1}$ lower than the rates of the other two associations in the eastern region.

The highest and lowest rates of emission of methane throughout the 15 irrigation associations were in Ping-Tung and Nan-Tou, with values of 1.4 and 0.06 $\mathrm{kg} \mathrm{ha}^{-1}$ day $^{-1}$, respectively. The acidic soil and the lowest temperature in Nan-Tou, and the neutral soil $\mathrm{pH}$ and the highest temperature in Ping-Tung were the most important contributing factors.

\subsubsection{Second crop season}

Fig. 4(e)-(h) plots simulated rates of emission of methane from paddies during the five rice growth stages in the second crop season in the northern, central, southern and eastern regions. The rate of emission of methane was highest during the transplanting stage, and gradually declined as the temperature fell and the methane oxidation rate increased. The southern region, in an area of high temperature and neutral soil had the highest emission rate, while the northern region, in an area of low-temperature and acidic soil, exhibited the lowest rate. The highest rates of emission of methane among all the irrigation associations in the northern and southern regions were found at Tao-Yuan and Ping-Tung, while the lowest rates among the irrigation associations in the central and eastern regions were evident in Nan-Tou and E-
Land, which were the same areas as in the first crop season.

The lowest rate, $0.06 \mathrm{~kg} \mathrm{ha}^{-1}$ day $^{-1}$, of emission among all 15 irrigation associations was at Nan-Tou, and the highest rate, $1.4 \mathrm{~kg} \mathrm{ha}^{-1}$ day $^{-1}$, was at PingTung. The corresponding associations were the same as in the first crop season.

\subsubsection{Comparison of first and second crop seasons}

Multiplying the rates of emission of methane by the paddy areas of the 15 irrigation associations yielded the total amounts of methane emitted during the first and second crop seasons-28,507 and 350,231 tons, respectively (Table 2). The total emission of methane from the paddy fields in 2001 was 378,738 ton/year; $7.7 \%$ was emitted in the first crop season, and $92.3 \%$ was emitted in the second crop season.

Chang (1996) used data measured in the field to estimate the amount of methane emitted during the first and second crop seasons in the northern region of Taiwan. The estimated results were 2539-3290 and $10,165-13,373$ tons, respectively, which were close to 2093 and 17,943 tons, evaluated using MEM for the same region.

Yang et al. (2003) estimated the amount of methane emitted from Taiwanese paddy fields from 1990 to 2000 , by applying a country-specific emission

Table 2

Amounts of methane emitted in the first and second crop seasons, for the 15 irrigation associations

\begin{tabular}{|c|c|c|c|c|c|}
\hline $\begin{array}{l}\text { Irrigation } \\
\text { association }\end{array}$ & $\begin{array}{l}\text { First crop MER }{ }^{\mathrm{a}} \\
(\mathrm{kg} / \mathrm{ha} / \text { day })\end{array}$ & $\begin{array}{l}\text { Second area MER } \\
(\mathrm{kg} / \mathrm{ha} / \text { day })\end{array}$ & $\begin{array}{l}\text { Paddy area } \\
\text { (ha) }\end{array}$ & $\begin{array}{l}\text { First crop } \\
\text { areal } \sum \text { (tons) }\end{array}$ & $\begin{array}{l}\text { Second crop } \\
\text { areal } \Sigma \text { (tons) }\end{array}$ \\
\hline Pai-Zi & 0.16 & 1.55 & 1435.23 & 25.26 & 244.71 \\
\hline Tao-Yuan & 0.23 & 2.04 & $20,534.89$ & 519.53 & 4608.03 \\
\hline Shih-Men & 0.12 & 1.05 & $11,461.90$ & 151.30 & 1323.85 \\
\hline Hsin-Chu & 0.15 & 1.42 & 6145.10 & 101.39 & 959.86 \\
\hline Miao-Li & 0.14 & 1.03 & 9681.46 & 149.09 & 1096.91 \\
\hline Tai-Chung & 0.71 & 9.32 & $23,379.77$ & 1825.96 & $23,968.94$ \\
\hline Nan-Tou & 0.06 & 0.59 & 3552.84 & 23.45 & 230.58 \\
\hline Chang-Hwa & 0.89 & 14.90 & $35,714.01$ & 3496.40 & $58,535.26$ \\
\hline Yun-Lin & 1.10 & 13.65 & $59,647.96$ & 7217.40 & $89,561.41$ \\
\hline Chia-Na & 1.28 & 13.55 & $49,422.86$ & 6958.74 & $73,664.77$ \\
\hline Kao-Shiung & 1.31 & 15.74 & 1296.92 & 186.89 & 2245.49 \\
\hline Ping-Tung & 1.40 & 18.28 & $24,132.89$ & 3716.47 & $48,526.42$ \\
\hline Tai-Tung & 1.01 & 12.27 & 6255.00 & 694.93 & 8442.37 \\
\hline Hwa-Lien & 1.12 & 13.24 & $18,616.00$ & 2293.49 & $27,112.34$ \\
\hline E-Land & 0.62 & 5.25 & $16,814.00$ & 1146.71 & 9710.09 \\
\hline Total & & & $288,090.83$ & $28,507.02$ & $350,231.03$ \\
\hline
\end{tabular}

\footnotetext{
${ }^{\mathrm{a}}$ Methane emission rate (MER).
} 


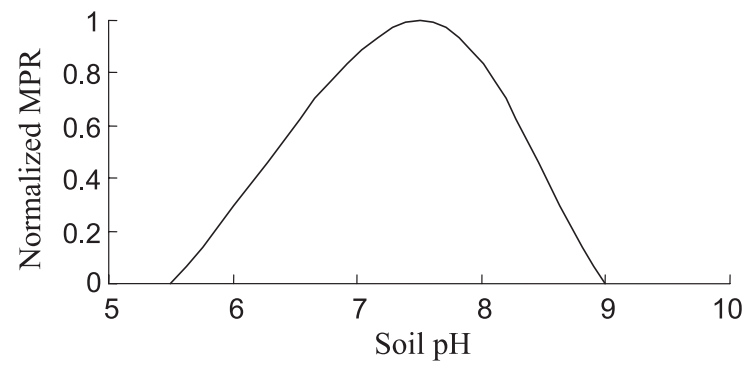

Fig. 5. Parabolic relationship between soil $\mathrm{pH}$ and the normalized methane production rate (MPR).

factor. Local data were unavailable so they used emission factors recommended by the IPCC 1997a,b). The estimated total amount of methane emitted was 37,073 tons in 1990 , decreasing to 25,678 ton in 2000 . These values were far lower than the current estimates of 378,738 tons in 2001, obtained using MEM. The MEM accounted for the processes of plant growth, organic matter degradation, methanogenesis, methanotropic oxidation and their quantitative relationships with environmental factors. According to the IPCC's guidelines, only the tabulated emission and corrected factors were used to estimate the amount of emitted methane in the five rice growth stages. The MEM, coupled with supporting data collected at 15 irrigation associations, would yield more reliable predictions than the estimates made according to IPCC guidelines.

\subsection{Sensitivity analysis}

The sensitivity of the methane emission rate of four parameters - soil $\mathrm{pH}$, temperature, soil water depth (SWD) and soil organic matter content were investigated. The input value of each parameter was varied by $\pm 10 \%$ and the corresponding methane emission rate was computed. The sensitivity to a parameter is given by

$S=\frac{E_{2}-E_{1}}{E_{1}} \times 100 \%$

where $S$ denotes the sensitivity, and $E_{1}$ and $E_{2}$ are the methane emission rates $\left(\mathrm{kg} \mathrm{ha} \mathrm{h}^{-1} \mathrm{day}^{-1}\right)$ before and after the change in the parameter, respectively.

The relationship between the $\mathrm{pH}$ and the methane production rate is described by a parabolic curve (Fig. 5). Slight alkalinity is generally recognized to promote the formation of $\mathrm{CH}_{4}$. The optimal $\mathrm{pH}$ for the production of several species of methanogens ranges from 6.4 to 7.8. Wang et al. (1993) observed that the $\mathrm{CH}_{4}$ production rate in paddy soil peaked at a $\mathrm{pH}$ between 6.9 and 7.1. A pH of below 5.75 or above 8.75 completely suppressed production. The limiting values were assumed to be 5.5 and 9.0, and 7.5 was taken as optimal. Tables 3 and 4 present the changes in the methane emission rates of the 15 irrigation associations as soil $\mathrm{pH}$ was varied by $\pm 10 \%$ in the first and

Table 3

Sensitivity analysis of the effect of soil $\mathrm{pH}$ on the methane emission rate in the first crop season

\begin{tabular}{|c|c|c|c|c|c|}
\hline & $\begin{array}{l}\text { MER } \\
\text { (kg/ha/day) }\end{array}$ & $\begin{array}{l}110 \% \mathrm{pH}-\mathrm{MER} \\
(\mathrm{kg} / \mathrm{ha} / \text { day })\end{array}$ & $\begin{array}{l}90 \% \mathrm{pH}-\mathrm{MER} \\
\text { (kg/ha/day) }\end{array}$ & $S(110 \% \mathrm{pH})$ & $S(90 \% \mathrm{pH})$ \\
\hline Pai-Zi & 0.16 & 0.11 & 0.23 & -32.92 & 40.39 \\
\hline Tao-Yuan & 0.23 & 0.19 & 0.29 & -18.31 & 22.98 \\
\hline Shih-Men & 0.12 & 0.07 & 0.18 & -39.60 & 48.74 \\
\hline Hsin-Chu & 0.15 & 0.09 & 0.22 & -39.60 & 48.74 \\
\hline Miao-Li & 0.14 & 0.08 & 0.21 & -39.55 & 48.87 \\
\hline Tai-Chung & 0.71 & 0.68 & 0.74 & -3.50 & 4.28 \\
\hline Nan-Tou & 0.06 & 0.02 & 0.06 & -39.55 & 48.87 \\
\hline Chang-Hwa & 0.89 & 0.89 & 0.90 & -0.55 & 0.58 \\
\hline Yun-Lin & 1.10 & 1.09 & 1.09 & -0.31 & -0.41 \\
\hline Chia-Na & 1.28 & 1.28 & 1.28 & -0.058 & -0.08 \\
\hline Kao-Shiung & 1.31 & 1.30 & 1.33 & -1.07 & 1.20 \\
\hline Ping-Tung & 1.40 & 1.40 & 1.41 & -0.56 & 0.57 \\
\hline Tai-Tung & 1.01 & 1.00 & 1.01 & -0.81 & 0.88 \\
\hline Hwa-Lien & 1.12 & 1.13 & 1.11 & 0.53 & -0.78 \\
\hline E-Land & 0.62 & 0.58 & 0.67 & -6.76 & 8.02 \\
\hline
\end{tabular}


Table 4

Sensitivity analysis of the effect of soil $\mathrm{pH}$ on the methane emission rate in the second crop season

\begin{tabular}{|c|c|c|c|c|c|}
\hline & $\begin{array}{l}\text { MER } \\
\text { (kg/ha/day) }\end{array}$ & $\begin{array}{l}110 \% \mathrm{pH}-\mathrm{MER} \\
\text { (kg/ha/day) }\end{array}$ & $\begin{array}{l}90 \% \mathrm{pH}-\mathrm{MER} \\
(\mathrm{kg} / \mathrm{ha} / \text { day })\end{array}$ & $S(110 \% \mathrm{pH})$ & $S(90 \% \mathrm{pH})$ \\
\hline Pai-Zi & 1.55 & 1.04 & 2.17 & -32.92 & 40.39 \\
\hline Tao-Yuan & 2.04 & 1.67 & 2.51 & -18.31 & 22.98 \\
\hline Shih-Men & 1.05 & 0.63 & 1.56 & -39.60 & 48.74 \\
\hline Hsin-Chu & 1.42 & 0.86 & 2.11 & -39.60 & 48.74 \\
\hline Miao-Li & 1.03 & 0.63 & 1.54 & -39.55 & 48.87 \\
\hline Tai-Chung & 9.32 & 9.00 & 9.72 & -3.50 & 4.28 \\
\hline Nan-Tou & 0.59 & 0.21 & 0.53 & -39.55 & 48.87 \\
\hline Chang-Hwa & 14.90 & 14.825 & 14.98 & -0.55 & 0.58 \\
\hline Yun-Lin & 13.65 & 13.60 & 13.59 & -0.31 & -0.41 \\
\hline Chia-Na & 13.55 & 13.54 & 13.53 & -0.05 & -0.08 \\
\hline Kao-Shiung & 15.74 & 15.57 & 15.93 & -1.07 & 1.20 \\
\hline Ping-Tung & 18.28 & 18.18 & 18.38 & -.56 & 0.57 \\
\hline Tai-Tung & 12.27 & 12.17 & 12.38 & -0.81 & 0.88 \\
\hline Hwa-Lien & 13.24 & 13.31 & 13.14 & 0.53 & -0.78 \\
\hline E-Land & 5.25 & 4.90 & 5.67 & -6.76 & 8.02 \\
\hline
\end{tabular}

second crop seasons, respectively. Of the 15 irrigation associations, Pai-Zi, Shih-Men, Hsin-Chu, Miao-Li and Nan-Tou had a large range of methane emission rates of $-33-49 \%$; this variation was caused by the acidic soil conditions ( $\mathrm{pH} 5.6$ ) and the large positive slopes in this part of the $\mathrm{pH}$ curve, as plotted in Fig. 5.

Temperature is one of the most important factors that govern the production of $\mathrm{CH}_{4}$. Temperature is positively correlated with both diurnal and seasonal variations in $\mathrm{CH}_{4}$ flux. The optimal temperature for production of most methanogens is from 30 to $40{ }^{\circ} \mathrm{C}$. Schutz et al. (1989) noted that the $\mathrm{CH}_{4}$ doubled as the temperature increased from 20 to $25{ }^{\circ} \mathrm{C}$. Hence, the effect of temperature (TEM) on the production of $\mathrm{CH}_{4}, f(\mathrm{TEM})$ was modeled by the equation,

$f(\mathrm{TEM})=\frac{e^{[0.334(\mathrm{TEM}-23)]}}{1+e^{[0.334(\mathrm{TEM}-23)]}}$

The change in the methane emission rate of 15 irrigation associations as the temperature was varied by $\pm 10 \%$ in the first and second crop seasons were $45 \%$ to $-39 \%$ and $52 \%$ to $-40 \%$, respectively.

The depth of flood water over soil may control the rate of $\mathrm{CH}_{4}$ production. Sebacher et al. (1986) found that $\mathrm{CH}_{4}$ emission rates increased with the depth of the flood water to a depth of up to approximately 10 $\mathrm{cm}$. The rate of $\mathrm{CH}_{4}$ production in continuously flooded paddy fields was assumed to be correlated linearly with the soil water depth (SWD).
The sensitivity analysis of the four parameters indicates that the temperature and soil organic matter content are positively correlated with the methane emission rate; that the soil water depth is inversely correlated with the methane emission rate, and the soil pH may be either positively or negatively correlated with methane emission rate, according to the initial soil $\mathrm{pH}$. The $\mathrm{pH}$ is the most important parameter that governs the methane emission rate in the five northern

Table 5

Comparison of rates of emission of methane obtained by retaining rice straw and those obtained by removing rice straw before the second crop season

\begin{tabular}{lcl}
\hline $\begin{array}{l}\text { Irrigation } \\
\text { association }\end{array}$ & $\begin{array}{l}\text { Retain rice } \\
\text { straw MER } \\
(\mathrm{kg} / \mathrm{ha} / \text { day })\end{array}$ & $\begin{array}{l}\text { Remove rice } \\
\text { straw MER } \\
(\mathrm{kg} / \mathrm{ha} / \text { day })\end{array}$ \\
\hline Pai-Zi & 1.55 & 0.14 \\
Tao-Yuan & 2.04 & 0.39 \\
Shih-Men & 1.05 & 0.23 \\
Hsin-Chu & 1.42 & 0.22 \\
Miao-Li & 1.03 & 0.10 \\
Tai-Chung & 9.32 & 0.01 \\
Nan-Tou & 0.59 & 0.96 \\
Chang-Hwa & 14.90 & 0.19 \\
Yun-Lin & 13.65 & 0.20 \\
Chia-Na & 13.55 & 0.12 \\
Kao-Shiung & 15.74 & 0.12 \\
Ping-Tung & 18.28 & 0.05 \\
Tai-Tung & 12.27 & 0.01 \\
Hwa-Lien & 13.24 & 0.49 \\
E-Land & 5.25 & 0.10 \\
\hline
\end{tabular}


Table 6

Changes in the depth of flood water during five rice growth stages for three types of irrigation

\begin{tabular}{lllc}
\hline Growth stage & $\begin{array}{l}\text { Traditional } \\
\text { depth }(\mathrm{cm})\end{array}$ & $\begin{array}{l}10 \mathrm{~cm} \\
\text { depth }(\mathrm{cm})\end{array}$ & $\begin{array}{l}25 \mathrm{~cm} \\
\text { depth }(\mathrm{cm})\end{array}$ \\
\hline Transplanting & 4 & 10 & 3 \\
Effective tillering & 4 & 10 & 25 \\
Booting & 5 & 10 & 25 \\
Blooming & 7.5 & 10 & 25 \\
Mature & 2.5 & 10 & 5 \\
\hline
\end{tabular}

irrigation associations because the soil $\mathrm{pH}$ is around 5.6. The order of the strengths of the effects of the other parameters as determined from the data collected by the northern irrigation associations, is temperature, soil water depth and soil organic matter content. In the central, southern and eastern irrigation associations, the order of the strengths of the effects of the four parameters are temperature, soil $\mathrm{pH}$, soil water depth, and soil organic matter content. Thus, the methane emission rate from paddies in Taiwan is most sensitive to temperature.

\subsection{Methane reduction strategy}

Taiwanese rice paddies are now facing considerable commercial competition from foreign growers of imported cheap, high-quality foreign rice, following
Taiwan's entry into the World Trade Organization in 2002. The Council of Agriculture has planned to reduce the area of paddy fields from 330,000 to 290,000 ha to reduce the amount of rice produced and thus stabilize its price. The initial plan is to rotate the planting of rice in the second crop season in the northern, central, southern and eastern regions in that order because the second crop season has relatively low yield and high production cost.

The amount of methane emitted in the second crop season was 7-16 times that emitted during the first crop season. If the reduction in planted acreage proposed (12\%) is during the second crop season, this will reduce the amount of methane emitted by $21 \%$ annually.

Additionally, the rice straw following the first crop harvest is ground into the soil before the rice is planted in the second crop season. The addition of ground rice straw to the soil significantly increases the rate of emission of methane in the hot and humid summer. Removing the rice straw from the soil greatly reduces the rate of emission of methane. Table 5 compares the rates obtained when the rice straw left until the second crop season with those obtained when the straw was removed. The rate of emission is generally reduced by an order of magnitude. The removal of rice straw may be a cost-effective means of substantially reducing methane emission in the

Table 7

Comparison of the rates of emission of methane obtained using the traditional $(6 \mathrm{~cm}), 10$ and $25 \mathrm{~cm}$ depths of flood water for irrigation

\begin{tabular}{|c|c|c|c|c|c|c|}
\hline \multirow{2}{*}{$\begin{array}{l}\text { Irrigation } \\
\text { association }\end{array}$} & \multicolumn{3}{|l|}{ First crop season } & \multicolumn{3}{|l|}{ Second crop season } \\
\hline & $\begin{array}{l}\text { Traditional MER } \\
(\mathrm{kg} / \mathrm{ha} / \text { day })\end{array}$ & $\begin{array}{l}10 \mathrm{~cm} \text { depth } \\
\operatorname{MER}(\mathrm{kg} / \mathrm{ha} / \text { day })\end{array}$ & $\begin{array}{l}25 \mathrm{~cm} \text { depth } \\
\operatorname{MER}(\mathrm{kg} / \mathrm{ha} / \text { day })\end{array}$ & $\begin{array}{l}\text { Traditional } \\
\text { MER (kg/ha/day) }\end{array}$ & $\begin{array}{l}10 \mathrm{~cm} \text { depth } \\
\operatorname{MER}(\mathrm{kg} / \mathrm{ha} / \text { day })\end{array}$ & $\begin{array}{l}25 \mathrm{~cm} \text { depth } \\
\operatorname{MER}(\mathrm{kg} / \mathrm{ha} / \text { day })\end{array}$ \\
\hline Pai-Zi & 0.16 & 0.34 & 0.13 & 1.55 & 3.52 & 1.26 \\
\hline Tao-Yuan & 0.23 & 0.48 & 0.19 & 2.04 & 4.68 & 1.67 \\
\hline Shin-Mem & 0.12 & 0.25 & 0.10 & 1.05 & 2.40 & 0.86 \\
\hline Hsin-Chu & 0.15 & 0.30 & 0.12 & 1.42 & 3.24 & 1.17 \\
\hline Miao-Li & 0.14 & 0.29 & 0.11 & 1.03 & 2.38 & 0.85 \\
\hline Tai-Chung & 0.71 & 1.48 & 0.58 & 9.32 & 21.20 & 7.62 \\
\hline Nan-Tao & 0.06 & 0.13 & 0.05 & 0.59 & 1.35 & 0.48 \\
\hline Chang-Hwa & 0.89 & 1.88 & 0.73 & 14.90 & 33.79 & 12.19 \\
\hline Yun-Lin & 1.10 & 2.31 & 0.90 & 13.65 & 31.14 & 11.19 \\
\hline Chia-Na & 1.28 & 2.71 & 1.06 & 13.55 & 30.90 & 11.11 \\
\hline Kao-Shiung & 1.31 & 2.82 & 1.08 & 15.74 & 35.24 & 12.89 \\
\hline Ping-Tung & 1.40 & 3.02 & 1.15 & 18.28 & 40.85 & 14.97 \\
\hline Tai-Tung & 1.01 & 2.09 & 0.82 & 12.27 & 27.87 & 10.02 \\
\hline Hwa-Lien & 1.12 & 2.34 & 0.91 & 13.24 & 30.05 & 10.79 \\
\hline E-Land & 0.62 & 1.29 & 0.51 & 5.25 & 12.03 & 4.28 \\
\hline
\end{tabular}


Asian countries because the temperatures in these countries are high and rice straw can be easily removed from paddy fields.

The rotational irrigation method is widely used in Taiwan. Floodwater to an average depth of $6 \mathrm{~cm}$ is normally maintained in paddies to reduce the amount of irrigation water required. Huang (2001) described deep-water irrigation as increasing the depth of flood water from 6 to $25 \mathrm{~cm}$. Deep-water irrigation reduces the time and cost of irrigation, yielding high-quality rice and enhancing groundwater recharge (Chen and Liu, 2002; Chen et al., 2002). The effect of increasing the depth of floodwater on the quantity of methane emitted from the paddy is of interest. Three depths of floodwater - the traditional $(6 \mathrm{~cm}), 10$ and $25 \mathrm{~cm}$ were considered. Table 6 presents the change in the depth of floodwater during the five growth stages of rice given the three types of irrigation. Table 7 lists the simulated rate of emission of methane for the three types of irrigation, in the first and second crop seasons. The rates of emission of methane at a flood water depth of $10 \mathrm{~cm}$ were generally double those obtained using the traditional irrigation method in both the first and the second crop seasons. When the depth of the floodwater was increased to $25 \mathrm{~cm}$, the emission rates were $18 \%$ below those obtained by traditional irrigation. Increasing the depth of floodwater to $10 \mathrm{~cm}$ does not reduce the rate of emission of methane, but significantly increases it. However, increasing the depth of the floodwater to $25 \mathrm{~cm}$ may reduce the rate of emission of methane, to the benefit of environment.

\section{Conclusions}

The study applies the methane emission model, which incorporates plant growth, climate and soil properties, to estimate the amount of methane emitted from rice paddy fields in Taiwan. The results indicate that most methane is emitted during effective tillering and booting stages in the first crop season and in the mature stage in the second crop season. The amounts of methane emitted in the first and second crop seasons were 28,507 and 350,231 tons, respectively, which values were one order of magnitude higher than those estimated using the IPCC guidelines. Moreover, the emission of methane in the second crop season was 12.5 times higher than that in the first crop season. Of all 15 irrigation associations, the highest and lowest rates of emission of methane were at PingTung and Nan-Tou, respectively. Sensitivity analyses indicated that the temperature is the most important parameter in determining the methane emission rate. The order of the strengths of the effects of the other parameters is soil $\mathrm{pH}$, soil water depth and soil organic matter content. Recessing 40,000 ha of rice paddies ( $12 \%$ of the total irrigated area) in the area of the southern irrigation associations with high methane emission to stabilize the rice price would reduce the emissions by 79,000 tons or $21 \%$ annually. Additionally, the emission of methane can be reduced and paddy field acreage preserved by implementing a remedial strategy to remove the rice straw following the first crop season which can reduce the methane emission rate by an order of magnitude, and increase the depth of the flood water to $25 \mathrm{~cm}$ which can reduce the methane emission rate by $18 \%$. Governmental agencies that are planning to recess rice paddies should carefully consider the posed strategy for reducing the amount of methane emitted.

\section{Acknowledgements}

The authors would like to thank the Chi-Shin Water Management Research and Development Foundation, and the National Science Council of the Republic of China for financially supporting this work under Contracts Nos. CH-91-CWL and NSC-912313-B-002-294, respectively.

\section{References}

Anastasic C, Dowding M, Simpson VJ. Future $\mathrm{CH}_{4}$ emission from rice production. J Geophys Res 1992;93:7521-5.

Barder DA, Martine JK. The release of organic substances by cereal roots into soil. New Phytol 1976;76:69-80.

Bouwman AF. Agronomic aspects of wetland rice cultivation and associated methane emissions. Biogeochemistry 1991;15: $65-88$.

Cao M, Dent JB, Heal OW. Modeling methane emission from rice paddies. Glob Biogeochem Cycles 1995a;9:183-95.

Cao M, Dent JB, Heal OW. Methane emissions from China's rice paddies. Agric Ecosyst Environ 1995b;55:129-37.

Chang CH. Rice planting. Taipei, Taiwan: Mau-Chang Press, 1988.

Chang, HL. Investigation of the methane emission and the influ- 
ential parameters in the Northern paddy field of Taiwan. PhD theses, Department of Agricultural Chemistry, National Taiwan University, Taipei, Taiwan, 1996.

Chen SK, Liu CW. Analysis of water movement in the paddy rice fields: (I). Experimental studies. J Hydrol 2002;260:206-15.

Chen SK, Liu CW, Huang HC. Analysis of water movement in the paddy fields: (II). Simulation studies. J Hydrol 2002;268: 259-71.

Delwiche CC, Cicerone RJ. Factors affecting methane production under rice. Glob Biogeochem Cycles 1993;7:143-55.

Holzapfel-Pschorn A, Conrad R, Seiler W. Effects of vegetation on the emission of methane from submerged paddy soil. Plant Soil 1986;92:223-33.

Houghton JT, Jenkins GJ, Ephraums JJ. Climate change: the IPCC scientific assessment. New-York: Cambridge University Press, 1990.

Huang, YS. Feasibility study the deep-water irrigation in the paddy field. MS thesis, Department of Bioenvironmental Systems Engineering. National Taiwan University, Taipei, Taiwan, 2001.

Huang SN. Methane emission and the influential factors in the eastern region of Taiwan. Hua-Lien Agric Improv Stn Rep 1996; $16: 35-46$

IPCC (Intergovernment Panel on Climate Change). Climate change 1992, the supplementary report to the IPCC scientific assessment. Cambridge: Cambridge University Press; 1992. p. 25-7.

IPCC (Intergovernment Panel on Climate Change). Guidelines for National Greenhouse Gas Inventories: workbook. Paris, France: OECD; 1997a [Chapter 4.3, Agriculture: Rice Cultivation].

IPCC (Intergovernment Panel on Climate Change). Guidelines for National Greenhouse Gas Inventories: reference manual. Paris, France: OECD 1997b [Chapter 4.3, Agriculture: Methane Emission from Rice Cultivation].

IRRI (International Rice Research Institute). Toward 2000 and beyond. Manila: International Rice Research Institute 1988.

Kludze HK, Delaune RD, Patrick Jr. WH. Aerenchyma formation and methane and oxygen exchange in rice. Soil Sci Soc Am J 1993;57:386-91.

Lin HC. Carbon-flux and methane emission conditions in the Paddy Fields. Annual project report. Taiwan: National Research Council 1995.

Liu CM, Yang SS, Hong CC. Emission of methane and nitrous oxide in Taiwan in 1990. J Biomass Energy Soc China 1996; $15: 1-8$.

Neue HU, Scharpenseel HW. Gaseous products of decomposition of organic matter in submerged soil. Organic matter and rice. Manila: International Rice Research Institute 1984. p. 328-31.

Oritani T, Yoshida R. Some views on the improvement of sink capacity and source functions during the ripening period of rice plants. Jpn J Crop Sci 1984;53:108-9.

Rolston DE. Gas flux. In: Klute A, editor. Methods of soil analysis Second ed. Madison: ASA and SSSA 1986. p. 1103-19 (Agronomy Monograph No. 9).

Schimel J. Miorobes and methane. Nature 2000;403:375-7.

Schimel J. Trace gases soil. In: Bitton C, editor. Encyclopedia of environmental microbiology vol. 6. New York: John Wiley and Sons 2002. p. 3183-94.

Schutz H, Seiler W, Conrad R. Processes involved in formation and emission of methane in rice paddies. Biogeochemistry 1989; $7: 33-5$.

Sebacher DI, Harriss RC, Bartlett KB, Sebacher SM. Atmospheric methane sources: Alaskan tundra bogs, an alpine fen and a subarctic boreal marsh. Tellus 1986;38B:1-10.

Segers R. Methane production and methane consumption: a review of processes underlying wet land methane fluxes. Biogeochemistry 1998;41:23-51.

Walter BP, Heimann M, Shannon RD, White JR. A process-based model to derive methane emissions from natural wetlands. Geophys Res Lett 1996;23:3731-4.

Wang ZP, Delaune RD, Masscheleyn PH, Patrick Jr WH. Soil redox and $\mathrm{pH}$ effects on methane production in a flooded rice soil. Soil Sci Soc Am J 1993;57:382-5.

Wang YP, Hsieh SW. Emission and environmental conditions of paddy soil, wetland, dryland, upland soil and forest soil in the central and southern Taiwan area. In: Lu SC, Liu CM, Yang SS, editors. Research on atmospheric environments of Taiwan area. Global Change Research Center and Department of Agricultural Chemistry. Taipei, Taiwan: National Taiwan University 1997. p. 99-121.

Watson A, Stephen KD, Nedwell DB, Arah JRM. Oxidation of methane in peat: kinetics of $\mathrm{CH}_{4}$ and $\mathrm{O}_{2}$ removal and the role of plant roots. Soil Biol Biochem 1997;29:1165-72.

Wuebbles DJ, Hayhoe K. Atmospheric methane and global change. Earth-Sci Rev 2002;57:177-210.

Yamane I, Sato K. Decomposition of glucose and gas formation in flooded soils. Soil Sci Plant Nutr 1964;10:127-33.

Yang SS, Chang HL. Effect of environmental conditions on methane production and emission of paddy soil. Agric Ecosyst Environ 1998;69:69-80.

Yang SS, Chang HL. Effect of green manure amendment and flooding on methane emission from paddy fields. Chemosphere, Glob Chang Sci 2001;3:41-9.

Yang SS, Liu CM, Lai CM, Liu YL. Estimation of methane and nitrous oxide emission from paddy fields and uplands during 1990-2000 in Taiwan. Chemosphere 2003;52:1295-305. 